\title{
Making Sense of Violent Events in Public Spaces
}

\author{
Citizens' Cognitions and Emotions of Society and Self \\ in Relation to Mediated Violence
}

\author{
Birgitta HöIJer \& Joel Rasmussen
}

\begin{abstract}
Violence in public spaces gives headlines in the media and is an issue of great concern for the public. It is threatening both on the societal and private level and shakes our belief in the rational and secure social world that was formulated by modernity and the welfare state. The article takes it point of departure in unforeseeable violent events in public spaces that in the media are labelled acts of madness and in which the perpetrators are pointed out as suffering from mental disorders. Results are presented from a study of how citizens attach social and cultural meanings to such events and it is shown how the meanings can be understood in relation to transformations in the emotional-cognitive climate of contemporary society. A culturally conditioned fear and worry, dilemmas and processes of individualization are discussed as crucial dimensions in institutional and public thinking about society and everyday life.
\end{abstract}

Key Words: mediated violence, receptions research, focus groups, cognition, emotion

\section{Introduction}

"In a world of random violence, no one is safe", states the American sociologist Best (1999:9). He further argues that the focus on unforeseeable violence in the mass media spreads the view among people that "things are getting worse, that there are ever more violent incidents".

In September 2003, four days before the referendum on whether or not to join the European monetary union the Swedish foreign minister Anna Lindh was brutally killed in the middle of the day when she was shopping at NK (a department store in Stockholm). After the assassination of Prime Minister Olof Palme in 1986 people and politicians had once again been lulled into a belief in the open democratic society where public figures can freely move around. The murder shocked the nation, and politicians worldwide expressed their consternation and sorrow. The violent event, the public grief and the hunt for the murderer were extensively covered in the media. So were some other violent events in public rooms the same year: a man attacked people on the street with an iron bar, a man drove a car into a group of people, and a man stabbed a child to death on the grounds of a day-care centre. In all these cases people were killed and the killings were 
unprovoked in the sense that there was no personal relationship between the victims and the murderers. The perpetrators were described in the media as suffering from mental disorders, and the killings were labelled acts of madness. ${ }^{1}$

How were these mediated events understood and explained by the public? What emotions, social significations and meanings were attached to them? This article presents results from focus group interviews with citizens from different social and cultural background, and discusses them in relation to transformations in the socio-cognitive climate of contemporary society.

\section{Background}

The public is concerned about different negative developments in society, such as unemployment, environmental problems and growing violence. Violence in the form of crime, neo-Nazism and terrorism are in fact the social issues about which people are the most troubled when they think about the future of the nation (Dahlgren \& Höijer, 1997; Bennulf, 2001: figure 1). It is a typical theme in people's worries (Best, 1999; Madriz, 1997). Violence is threatening both on the societal and private level. It threatens the very foundations of security in social life. A study of experiences of threat and risk in an urban area shows that different forms of physical violence and crime are seen as the most serious threats to personal safety (Sandstig, 2003).

Although all violence is threatening, some violent acts are perceived as more generally threatening to the public than others, such as unprovoked violence in public places. The events mentioned above as being labelled acts of madness are of that type.

There is a growing use of the phrase 'act of madness' in the Swedish media (Höijer $\&$ Rasmussen, 2005). It has become popular in the headlines to signal sudden, unexpected inexplicable violence, which can happen to anybody. The same way of dealing with the subject has also been reported in media studies in other countries. A British study, for example, reported in Philo and Secker (1999) shows that mental illness and violence are often connected in headlines, and the perpetrators are described as 'mad', 'maniac' and 'psycho'. These labels refer to violent attacks as random, pointless and meaningless; the victims are encountered by chance (cf. Best, 1999).

There is however, implicit in the label 'act of madness', an explanation of the violence, namely that mental illness in itself may create aggression, a compulsion to suddenly attack other people and thus seriously hurt innocent victims. This may, of course, be moderated by other explanations in the media reporting, but a strong focus on the mental illness of perpetrators as a frame of reference for the understanding of violent acts will evidently risk fixating a causal common-sense connection between mental illness and violence at a general level. Dispositional attributions will be broadcasted and highlighted in major headlines, though the social-environmental context has been proven to be an essential part of the complex relation between cause and effect in violent crime (Swanson et al., 2002).

Attributing causes to events is a powerful way to make sense of social reality (Hewstone, 1989). It orders reality, or gives an illusion of order, of predictability and control. If we know the causes of violent acts we are, at least potentially, better equipped to place blame, hold responsible, take measures, and so on.

In a study of the media coverage in Sweden after the murder of the foreign minister Anna Lindh, we found that little attention was directed towards situational factors concerning perpetrators suffering from some type of mental disorder (Rasmussen \& Höijer, 
2005). Mental illness was dealt with in the media as an isolated phenomenon, and immediately considered the cause of violence. ${ }^{2}$ This interpretation of causal relations was repeated and consolidated in various ways. The debate on shortcomings in psychiatric care came to revolve around the psychiatric reform of 1995 and external conditions financial resources, compulsory legislation, the number of psychiatrists and beds in the institutional care. Other forms of care and the professional quality of psychiatric care were themes conspicuous by their absence. Media material that labels and emphasizes people suffering from mental illness as risk agents has implications for social policy decisions (Hallman, 2002; Philo and Secker, 1999).

\section{Transformations in the Emotional-cognitive Climate}

Our time is one of unrest characterized by structural and ideological transformations. Nations are multicultural, communication is globalizing, the technological development has fundamentally changed working life, market forces have been given free scope, political power is shifting from the nations to European and global levels, and environmental risks are global as are international terror threats. In some respects everyday life has become safer, for example, a cancer diagnosis is no longer a death sentence. In other respects there are increasing uncertainties and risks; we must constantly think about what to eat to keep us healthy, lock doors to stop thieves, avoid passing through dark parks, especially if we are female, and so on. In the media there is a growing focus on violence, and words such as fear, threat and risk are more commonly used (Altheide \& Michalowski, 1999; Furedi, 2002; Robertson, 2001; Sandstig, 2003).

We will here argue that fear, dilemma and individualisation colours the emotional and cognitive thinking of institutions and the public in contemporary society. The concept 'emotional-cognitive' is used to underline the symbiosis between emotions and cognitions. As called attention to by Nussbaum (2001) cognitive elements are essential parts of emotions, and as pointed out by others emotions are of critical importance to all aspects of social cognition (Bless, Fiedler \& Strack; 2003; Smith \& Kirby, 2000).

\section{Fear and Worry}

According to Furedi (2002) public fear based on media stories is increasing in the West. Via the media we hear about a wide variety of health and food scares, global epidemics, environmental risks, terrorism and crime. Fear has become commercialized and politicized. This has been exploited by a growing security industry with its burglary protection, private guards, assault alarms, and different kinds of surveillance systems. In politics, as noted by Eriksson (2001: 2), 'legislation initiatives related to threat and risks have increased dramatically'. There are a variety of new crisis and security authorities and institutions at national and international levels.

Fear is, however, a strong emotion: 'an unpleasant emotion caused by the threat of danger, pain, or harm '3 ${ }^{3}$ It may sometimes be more proper to talk about worry or concern as a characteristic of the emotional-cognitive climate of present society. People are, as mentioned above, worried or concerned about negative developments in society. Worry means to 'feel or cause to feel troubled over actual or potential difficulties'. ${ }^{4}$

Emotions such as social fear and worry involve beliefs about something bad that may happen, social cognitions about some present or future social reality (cf. Elster, 1999). ${ }^{5}$ "In order to have fear", writes Nussbaum (2001: 28), 'I must believe that bad events are 
impending; that they are not trivially, but seriously bad; and that I am not entirely in control of warding them off'. In the same way worrying is a feeling connected to social cognition of situations, events, developments, and so on. Boehnke et. al. (1998) makes a useful distinction between macro and micro worries, the former referring to worries about socio-political problems and the latter to problems close to the self. It is also worth noting that research show that macro-social worries, for example about environmental risks, may be positively related to political engagement (Marcus, 2002; Ojala, 2004).

\section{Dilemma}

A culturally conditioned worry, sometimes outright fear, is thus one dimension of institutional and public thinking and feelings about contemporary society and everyday life. Another dimension is that people are facing dilemmas, and experience ambivalence (Höijer, Lidskog \& Uggla, in press).

Our age of late modernity is characterized by partially contradictory trends and processes such as globalization and nationalism, a safer society and an increase of risk and fear, increased scope for personal choice and dependency on economic, structural and technical changes beyond individual control. In combination with the uncertainty of knowledge and predictions of the future, and the absence of ideological guidance as to what is right and wrong, this gives rise to feelings of ambivalence. Disagreements among experts are exposed in the media. Are climate changes caused by man or are they just natural variations? Is the radiation from mobile phones dangerous or not? Is violence increasing in society or not? In the development of modernity there was a strong belief in true knowledge, in scientific and technological progress and in social welfare based on expertise and political decisions. Also ideology in the form of a variety of religious movements, temperance organizations and labour movements fostered and guided people's thinking and behaviour. Today knowledge is called into question and political ideologies are dismantled and blurred and provide few clear alternatives to hold to. Furthermore, there is a growing variety of and pluralism in views and lifestyles (Gibbins \& Reimer, 1999). Our social beliefs and emotions may also become hesitant and changeable.

These uncertainties and ambiguities imply that people and institutions are faced with multidimensional dilemmas in which complex, precarious, and partially contradictory knowledge, judgements, and values are included. Höijer, Lidskog and Uggla (2006) give the following definition of a multidimensional dilemma: 'a culturally embedded doublefaced phenomenon in which a situation and/or discourse characterized by uncertainty, contradictions or conflicts, is related to cognitions and feelings of ambivalence in individual or institutional thinking'. This is brought to a head when unforeseen and dramatic events take place or threatening situations are confronted. Ambivalent emotions and cognitions may arise. Ambivalence is defined by Bauman (1991:1) as 'the acute discomfort we feel when we are unable to read the situation properly and to choose between alternative actions'. It has to do with having mixed or contrasting feelings and cognitions or oscillating in one's views (Reber, 1985).

There may be different types of dilemmas, for example moral dilemmas based on conflicting or contradictory moral values, or goal related dilemmas in which short-term goals contradict long-term goals. To mention just two typical examples: maintaining an open society can be hard to combine with demands for control and protection against threats and violence; creating jobs by locating industrial production in a certain area may 
be connected with reduction of unemployment but also with environmental and health risks in the future.

\section{Individualization}

According to Bauman (2001), the individualization of society and its influence on everyday life is something that social research must recognize and take into consideration. This process means that we to an increasing degree are set free from traditions and firm social structures such as class, nuclear family and gender roles. We are 'free', or rather, forced to choose our way of life and manage problems by ourselves. We are even fated to make individual choices. In the words of Beck and Beck-Gernsheim 2002: 4):

One of the decisive features of individualization processes, then, is that they not only permit but they also demand an active contribution by individuals. [...] Opportunities, dangers, biographical uncertainties that were earlier predefined within the family association, the village community, or by recourse to the rules of social estates or classes, must now be perceived, interpreted, decided and processed by individuals themselves.

They speak about a 'precarious freedom' centred on imperatives such as think, calculate, plan, adjust, negotiate, define and revoke. 'The choosing, deciding, shaping human being who aspires to be the author of his or her own life, the creator of an individual identity, is the central character of our time' (Beck \& Beck-Gernsheim 2002: 23).

It is important to note, however, that Beck as well as Bauman regards individualization as collectively forced upon us by neo-liberalism, the new global economy, commercialism, and so on. Individualization is a condition which is 'not arrived at by a free decision of individuals [...] people are condemned to individualization' (Beck \& BeckGernsheim, 2002: 4). In other words we can talk about processes of individualization as ideological processes as well as identity processes. Bauman (2001) speaks about an institutionalized individualism. Problems earlier regarded as structural, for example, unemployment and ill-health, are today individualized, and are converted to private problems where the individuals are blamed.

\section{Cognitions and Emotions of Society and Self}

The following discussion is based on results from focus groups on how citizens reacted to, understood, and explained mediated violent events in public spaces, especially the murder of foreign minister, Anna Lindh. With processes of making meaning in the centre, a qualitative study was a suitable choice of method (Kvale, 1996). Fifteen focus groups, in most cases gender-homogeneous (13 groups), were carried out comprising a total of 51 persons. Besides gender the groups differed in social background, age and ethnicity so as to cover possible variations in reactions and views. ${ }^{6}$ Since small groups have been proven to create greater openness and equality in communicative situations than larger groups (Höijer \& Olausson, 2003) ${ }^{7}$ the number of participants in each group, with two exceptions, varied between three and five individuals. The study is documented in its entirety in Höijer and Rasmussen (2005). The participants will hereafter be referred to as informants.

In their reactions and interpretations of the violent acts the informants contextualized the events and related them to social cognitions of the changes in society, more precisely 
of powerful actors and institutions, and to basic emotions, norms and evaluations emanating from social experiences of private life. The media reporting played an important role for the social cognitions although many informants also held quite critical views on how the media frames violent acts. The interpretations and reactions had a broad basis and consisted of beliefs and arguments about individuals, institutions and causal connections as well as feelings of sorrow, compassion, worry, anger and dissociation, and normative reasoning about power elites and citizens, crime and punishment. They also revealed different identity positions. Experiences from the private sphere, mostly shared by many, were drawn into the interpretations together with social cognitions emanating from the media and occupation spheres of life.

\section{The Complex Character of Fear and Worry}

Many informants expressed strong feelings and reactions to the violent acts, especially the murder of Anna Lindh. They spoke of shock, consternation, feelings of emptiness, and grief and disappointment over the nation's loss of a competent and well-liked politician. In particular this was true of the immigrant groups and the senior citizens. The younger informants spoke of weaker and more dissociated reactions.

The emotions were integrated into cognitions of society and self; in fact they seemed to be based on specific socio-cultural perspectives and views. In the first quote below by a female immigrant, shock and fear are expressed on the basis of ideologically coloured contradictory cognitions of the state of the nation: "You never thought this could happen here in Sweden. In the middle of the day! [...] But so many bad things are taking place now." Note also how self identity is involved in the fear reaction. In the second quote, by a male immigrant, a political explanation of collective and personal grief is put forth. Ethnic identity and personal identity are drawn into the reaction as well. The third quote, by a young male student, shows how informants could use critical social cognitions of the mass media, and thereby keep their own emotional involvement back. By focusing on the messenger the violent act is diminished.

It was terrible when I first heard about it [the violent attack on the foreign minister]. It's mad. I never thought this could happen here in Sweden. In the middle of the day! I couldn't believe it. But so many bad things are happening nowadays. In the afternoon, at four o'clock! I really get afraid.

Anna Lindh was both competent and courageous. [...] We Kurds respected her very much. I remember her speech on the fear of Turkey invading northern Iraq or Kurdistan. She warned Turkey that there would be consequences. It was especially sensitive for us and for me personally.

My first thought was that it was a mere trifle. I didn't think it was very serious. I followed the news but I wasn't afraid. I thought that the media as usual had exaggerated the whole thing.

Compared to shock and consternation, worry is a more prolonged emotional-cognitive reaction. Through its long lasting, sustained, gnawing character, worry colours interpretations of public and private courses of events and influences one's freedom of action. It is not like a shock attached to a specific event, but rather a more blurred emotioncognition. Worry develops and is strengthened in small steps over a long period of time and relates to experiences of a variety of events and social phenomena. Worry transforms, consolidates or grows weaker in the interplay between self and mediated expe- 
riences. For some, worry contributes to pessimism and passivity, for others it is an incentive to social engagement and activity (cf. Ojala, 2004).

The collective worry reflected in the focus groups was, as also found in earlier studies (Dahlgren \& Höijer, 1997), complex and connected with cognitions of society and self. The female informants, immigrant groups and senior citizens expressed much stronger worry than the other groups. Some of the young men said that they did not feel any worry at all, and some other groups said that they felt some worry but that it was very much in the background of their everyday lives.

There was a female macro-micro worry in which cognitions of escalating violence in society, of a deepening negative development, gave rise to macro worries about society as well as micro-worries about their own safety and that of their families in everyday life. The informants enumerated many different types of violent events known from the media. They expressed consternation and worry and told about their own fear of violence, not least of being raped, and fear of violence against their children. This quote is from a female student:

There are no longer any limits to the violence against innocent people. So many things are happening now. There is more and more violence. I have a feeling that you can't keep it away anymore. You can't say: 'this will not happen to me'. It is coming closer to you.

Fear and worry about increased violence and crime were related to reduced social welfare, macro-worries about negative changes in working life, cutbacks in public medical service including psychiatric care, shortcomings in the police system and lack of competence among politicians to solve the problems of society. Some informants - especially some immigrant groups - expressed a fear related to the experience of a growing passivity among citizens when it comes to intervening when they witness wrong or violent acts in public places. If no one takes measures when people are in danger; what will happen in a situation when someone is attacking you? Another worry among the immigrant groups was related to immigrant perpetrators and the fear of growing ethnic discrimination as a consequence of stereotypical cultural generalizations or collective blaming based on single deviant cases:

The first thing you think when there is a bank robbery or a murder is that you hope that the perpetrator will not be an immigrant. It makes you feel guilty somehow. And a kind of witch-hunt on us will come about. After the first shock when [the foreign minister] Anna Lindh had been killed I thought: I really hope that the perpetrator is not an immigrant.

\section{Dilemmas and Ambivalences}

The informants expressed emotions and reasoning of the type 'on one hand, and on the other hand' many times. They turned the problems and perspectives over and over in their mind and regarded and evaluated the events and courses of events from different angles. This reflexivity is positive since reasoning and feeling are prerequisites for a democracy in which citizens discuss and are engaged in social questions and problems. Sometimes the reflexivity brought the informants into dilemmas and they experienced ambivalence because the different perspectives contained partly inconsistent cognitions and emotions.

Dilemmas have often been seen as problems, hindrances or obstacles, which one needs to overcome in order to come to a conclusion, or make a proper decision, and so 
on. And sometimes a dilemma with a deep feeling of ambivalence may block the line of thought and action and lead to passivity and paralysis. It is, however, important to recognize that dilemmas may be highly enabling and function as the basis of reflexivity, deliberation, and creativity (Höijer, Lidskog \& Uggla, in press). It could be interesting to note that as studies of participatory processes show, non-experts or laymen are often more willing than experts to embrace pluralistic perspectives (Healy, 2003). Another way to put it is to say that people in general may be more reflexive and open minded than experts fighting for a certain view. This reflexivity of mind is especially emphasized in theories of late modernity where it is also understood as a specific historical and cultural phenomenon. The world that we experience is global, and to an increasing degree mediated through electronic and print media. The world of late modernity we experience no longer corresponds to the world we interact with through concrete and direct experiences. As Giddens (1991: 188) puts it 'all individuals actively, although by no means always in a conscious way, selectively incorporate many elements of mediated experience into their day-to-day conduct'. This gives rise, according to Giddens, to various tensions, which can be analysed as dilemmas. Thus there may be contradictions and dilemmas found in the intersection between social cognitions based on the media and social cognitions based on one's own experiences. Each of these spheres of experience may also in themselves be full of tensions and contradictions giving rise to dilemmas and ambivalences.

The informants felt, for example, ambivalence about the police authority and the work of the national police corps in general. The same informants could on the one hand express a very strong critique of and low level of confidence in the police. Further on, they brought up serious failures, such as the large number of crimes that are not solved or even investigated. On the other hand, the informants showed empathic understanding of the policemen and their work. They pointed to the over burdened, well-nigh impossible working situation of the policemen. The dilemma underlying these ambivalent feelings arises from the conflict between two different social and human perspectives, between which the informants vacillated between. In the first perspective the informants took a stand for the victims of the violence and regarded the social scene from the horizon of actual or potential victims, sometimes including themselves. From such a perspective the police are blameworthy since they often do not catch the perpetrators and prevent violence and crime. They are, accordingly, not doing their job very well:

It is their job to catch criminals. What did they do when Anna Lindh was attacked? Why did they not block the mall and stop people from leaving? I have the feeling that you cannot trust the police anymore. [...] They do not care about you when you call them and ask for help. [...] I am really very critical.

In the second perspective the informants took a stand for the police, who then appeared less blameworthy since the policemen were thought of as doing their very best, despite limited authority, in a difficult and hopeless working situation:

They [the police] are also human beings. I must defend them because they do have limited resources. If they get the order to catch someone they will do it. But there are so many limitations in their work. [...] If they would be given more free agency they would certainly prevent crimes.

Another ambivalence concerned social cognitions of mental illness and violence. On the one hand, some informants criticized the fact that people with severe mental disorders 
are institutionalized to a lesser extent due to the changes in psychiatric care after the psychiatric reform of 1995: "A lot of people with mental disorders are walking around. And you cannot recognize who they are. Of course you feel unsafe." On the other hand the informants showed strong sympathy for people suffering from mental disorders and declared that they did not believe in a return to large-scale institutionalization of users of services: "It is not only a bad thing [the psychiatric reform]. It is a good thing for many of them to be out in society living their own lives. It helps them to feel better." The informants shifted between two authoritative norms, the one originating from the obligation of a society to protect its citizens, and the other from the right of all citizens, including those suffering from mental disorders, to live a decent everyday life. The ambivalence arose because the informants could not find a solution to the normative and ethical dilemma of simultaneously protecting citizens from potentially dangerous individuals and upholding the integrity and quality of life of people suffering from mental disorders. It is reasonable to suppose that the media reporting focusing on people suffering from mental illness as risk agents (Rasmussen \& Höijer, 2005) influences people's perceptions of this heterogeneous group as dangerous.

A third example of ambivalence pertained to the media reporting of the violent events in public spaces. The informants could, from a general point of view, acquire adopt a critical perspective towards the media, and display little confidence in the reporting, and yet talk about a less sceptical attitude in their everyday contact with the media. In their mundane media consumption they believe that what they read, listen to and watch is true. Shifting between holding a generally critical perspective towards the media and accepting the media reports as true descriptions of reality is the result of a conflict between the need to acquire reliable knowledge about events and developments in the surrounding world and an awareness that the media is part of a commercial marketplace slanting and dramatizing in the struggle for people's attention. The dilemma is temporarily solved when the informants hold back their more critical perspectives during their immediate, every-day media consumption:

For a long time I have known that I cannot trust the media. This becomes more acute in relation to events like this [violence in public spaces]. But one becomes indifferent in the end. You read in the newspapers and once again you believe it is the truth. It was the same thing when Olof Palme was assassinated. You believed everything, but after a while many errors in the media were revealed.

\section{Interpretation Perspectives of Individualism and Collectivism}

As already pointed out, social theorists claim that processes of individualization permeate society. Individualistic ideals are replacing collectivistic ideals and solutions. It is also claimed that citizens' thinking follows individualistic ideologies more and more.

The social cognitions of the informants in the present study demonstrated both individualistic and collectivistic lines. There was a clear difference between the immigrant groups, which mainly emphasized collective ideals and identities, and the native Swedes who tended to emphasize the individual, especially the young ones. The immigrants, for example, told about how they came together in collective grief after the murder of foreign minister Anna Lindh, while such stories were absent among the native Swedes. Some of the latter even thought that the television and newspaper pictures of collective manifestations of grief, such as minutes of silent at working places and ceremonies in churches, seemed unreal and forced. Grief is something individual one ought to keep to 
oneself. As a young women said: "I don't think that Swedes are like that [mourning collectively in public]. We all sit in our small houses. We may be sad each in our own places." The first quotation below, illustrating collectivism, is from a focus group of Syrian immigrants and the second quotation, illustrating individualism, is from a focus group of young Swedes.

We share the sorrow and talk to each other. [...] We held a service to her memorial in our church. Children and women and men all stood up to honour her and prayed. It was a very special service. [...] We want to uphold peace and the whole assembly said the Lord's Prayer just for her.

I asked myself if people really thought it was so painful or if it was just a play to the gallery because it was considered right to see it as a terrible and traumatic experience. [...] I could not notice such reactions in my surrounding as those shown on television and in the media. Public crying and hysterical crowds.

Collective perspectives were also expressed among the immigrant groups in other ways. As mentioned, informants told about a feeling of collective guilt if the perpetrator was of the same ethnic background as them: "If someone from Somalia had conducted the crime we would say we all had committed the crime. It would have become a collective responsibility." Informants described another collective responsibility as citizens as well, a duty to show compassion and intervene if they witnessed violence or crime. In such a normative ethical perspective native Swedes were considered all too passive, indifferent and individualized. The fact that no one took measures or acted when the foreign minister was attacked was regarded a consequence of the individualism in the Swedish society:

It is a very interesting question here about the individual who should mind his own business and not care about others. [...] In this country nobody reacts. [...] People don't care. They just want to save their own skin. There is something wrong with such a society.

Some of the domestic groups were also strongly critical to that nobody intervened when a man with a knife assaulted the foreign minister. But here the informants did not reason in terms of responsibility and courage. Instead they brought up institutional critiques, such as the lack of guards in the store in general and that no bodyguards accompanied the foreign minister. They also expressed understanding of the fact that the man in the street did not take action. The explanation given was that people became shocked and paralyzed in the face of the dreadful event. The causes attributed to the passivity were thus individualized and localized to internal psychological reactions:

It can be a panic thing - that you would like to intervene because it is something you ought to do, but then everything happens so darn fast, so before you even register what has happened the perpetrator has left the building.

It is, however, important to note that even the domestic informants brought up complicated social contexts when reasoning about the increasing violence in society. The interpretative frames changed from individualistic ones to more societal ones depending on whether single events or series of similar events were being interpreted and understood. It may be a result of the fact that ethnic Swedes are oscillating in their mental structuring of the world between new individualistic ideologies of late modernity and societal and collective ideologies of modernity. Processes of individualization have not 
totally thrown aside institutional and collectivistic thinking, which has fostered people during most of the long social-democratic era. Having your background in a non-Western culture means that you also bring in a sense of social responsibility and collectivistic thinking and sometimes, as in this study, in combination with a critical awareness of the disadvantages of an ideology of individualization. When comparing the immigrant informants with the domestic ones it was, however, obvious that the latter tended to have more individualistic perspectives and the discourse of civic responsibility was conspicuous by its absence in many groups.

\section{Conclusion}

Media representations of violence in public spaces meet us as audience to an increasing degree. Terrorism is without a doubt the most serious threat to security in public places, as recently underscored by the acts of terror in London in July 2005. Since London has more than seven million inhabitants with a mix of cultural backgrounds and is a popular place for people from the whole world to visit, many were directly or indirectly affected by this violence. But for most citizens in democracies terrorism is something that happens abroad, not something you risk meeting on your way to work, at workplaces or schools or when shopping in everyday life. Here the media instead paint a picture of violence conducted by different types of 'madmen', some with distorted sexual motives, others without any other purpose than aggression.

As citizens we are compelled to interpret and react to violence presented to us as random, unexpected, a threat that can be forced upon anybody who may by chance be at the wrong place at the wrong time. There may be many, complex and different, reasons behind unprovoked violence in public places but gratuitous brutality challenges citizens' emotions and social cognitions of safety in everyday life both at societal and individual levels.

Risk and safety are fundamental questions occupying the public sphere of late modernity. The politicians, social institutions, industry and media are all involved in risk and safety discourses. And from the point of view of the public violence occupies a central position in thinking about risk and safety. Violence shakes our belief in the rational and secure social world that was formulated by modernity and the social welfare state. Reactions to violent events are therefore interesting to study since they may bring out features of the emotional-cognitive climate of contemporary society.

As shown in this article, in making sense of violent events in public spaces citizens use a whole set of emotional-cognitive frames of reference. There are, of course, differences between individuals and groups. Some have been mentioned above. But the focus here is on the more general trends. In brief, the outrages were seen as consequences of negative trends in society in which the welfare state is being undermined, the social climate is hardening, a wave of meaningless, indiscriminate and unpredictable violence is increasing, the police are not able to tackle violence and crime, the psychiatric care organization is not taking care of people with severe mental disorders, and citizens do not intervene when they witness something wrong. The results underline the reflexive and critical nature of citizens' emotional-cognitive reception of violent events. The perspectives are turned over in people's minds and the reactions and interpretations are compounded. We have tried to show how they are related to transformations in the emotional-cognitive climate: fear and worry, dilemma and individualization. Apparently many position themselves in between 'old' ideologies of security in the welfare state and 
collective responsibility and the 'new' climate of fear and the ideology of individualization. Others are either more firmly rooted in the former or the latter. Ambivalent feelings and cognitions arise as a result of the dilemmas that citizens are confronted with in a period of economic, social and ideological changes in society. Old and new ideologies and identities live side by side and colour people's reactions to and interpretations of violent events in public spaces.

\section{Notes}

1. Some, however, regard the murder of the foreign minister as having been provoked by her public support of NATO during the bombings of Serbia in the Kosovo war, in Spring 1999 (as noted in Aftonbladet, 2003-09-27). Unlike the perpetrators in the other three cases, the murderer of Anna Lindh, Mijailo Mijailovic, was after some controversy judged not to be suffering from a severe mental disorder, and was consequently sentenced to imprisonment instead of forensic psychiatric care.

2. According to Walsh and Fahy (2002) violent attacks committed by patients with psychotic illnesses occur somewhat more frequently than violent attacks by people in general. Male sex, young age, and low socio-economic status are, however, variables that show stronger connections with violence than mental illness. Further on, the causes of violence committed by people suffering from mental illness are usually found in combination with many factors, such as post-traumatic experiences, drug abuse, alcohol influence, and so on (Swanson, et. al., 2002).

3. The Concise Oxford English Dictionary, www.oxfordreference.com

4. The Concise Oxford English Dictionary, www.oxfordreference.com

5. There may also be an innate fear evoked in us, for example by a sharp strange sound, an unexpected rapid move, and so on.

6. The following groups were run: male students; female students; age and gender mixed manual workers, female employees; female shop assistants; male employees; male senior citizens; female senior citizens; male retired manual workers; gender mixed with psychiatric experiences; male Kurdish immigrants, male Somalian immigrants; female Somalian immigrants; male Syrian immigrants; female Syrian immigrants.

7. In groups of six particpants or more there is a higher risk of group pressure pushing people to express similar views and that one person takes the lead and dominates the talk.

\section{References}

Altheide, D. \& Michalowski, R.S. (1999) 'Fear in the News: A Discourse of Control', The Sociological Quarterly 40(3): 475-503.

Bauman (1991) Modernity and Ambivalence. Cambridge, UK: Polity Press.

Bauman (2001) The Individualized Society. Malden, MA: Polity Press.

Beck, U. \& Beck-Gernsheim, E. (2002) Individualization. Institutionalized Individualism and its Social and Political Consequences. London: Sage.

Bennulf, M. (2001) Opinion 2001. Nya hot och risker. Den svenska allmänhetens syn på samhället, säkerhetspolitiken och försvaret. [Opinion 2001. New Threats and Risks]. Stockholm: Styrelsen för psykologiskt försvar (Meddelande nr. 160).

Best, J. (1999) Random Violence. How We Talk about New Crimes and New Victims. Berkely and Los Angeles: University of California Press.

Boehnke, K., Schwartz, S., Stromberg, C. \& Sagiv, L. (1998) 'The Structure and Dynamics of Worry: Theory, Measurement, and Cross-National Replications', Journal of Personality 66(5): 754 -782.

Bless, H., Fiedler, K. \& Strack, F. (2003) Social Cognition. How Individuals Construct Social Reality. UK: Taylor \& Francis Ltd.

Dahlgren, P. \& Höijer, B. (1997) Medier, oro, medborgarskap. [The Media, Worry and Citizenship]. Stockholm: Styrelsen för psykologiskt försvar (report nr. 141).

Eriksson, J. (2001) 'Introduction', in Eriksson, J. (ed) Threat Politics. New Perspectives on Security, Risk and Crisis Management. Aldershot, UK: Ashgate, pp. 1-18

Elster, J. (1999) Strong Feelings. Cambridge, Mass.: The MIT Press.

Gibbins, J.R. \& Reimer, B. (1999) The Politics of Postmodernity. London: Sage.

Giddens, A. (1991) Modernity and Self-Identity. Cambridge: Polity Press. 
Hallam, A. (2002) 'Media Influences on Mental Health Policy: Long-term Effects of the Clunis and Silcock Cases', International Review of Psychiatry 14: 26-33.

Healy, S.A. (2003) 'Epistemological Pluralism and the 'Politics of Choice”, Futures 35(7): 689-701.

Hewstone, M. (1989) Causal Attribution. From Cognitive Processes To Collective Beliefs, Oxford, UK: Basil Blackwell.

Höijer, B. \& Olausson, U. (2003) Norska och svenska medborgare om medierna och Kosovokonflikten. [Norweigian and Swedish Citizens about the Media and the Kosovo Conflict]. Örebro Universitet: Studier i kommunikation och medier.

Höijer, B. \& Rasmussen, J. (2005) Medborgare om våldsåd. Reaktioner efter mordet på Anna Lindh och andra dåd. [Citizens about Acts of Violence. Reactions after the Murder of Anna Lindh and Other Crimes]. Stockholm: Krisberedskapsmyndigheten (report nr. 10).

Höijer, B., Lidskog, R. \& Uggla, Y. (2006) 'Facing Dilemmas. Sense-Making in Late Modernity', Futures, 38: 350-366.

Kvale, S. (1996) InterViews. An Introduction to Qualitative Research Interviewing. Thousand Oaks, California: SAGE.

Madriz, E. (1997) 'Images of Criminals and Victims: A Study on Women's Fear and Social Control', Gender and Society 11(3): 342-356.

Marcus. G.E. (2002) The Sentimental Citizen. Emotion in Democratic Politics. University Park, Pennsylvania: The Pennsylvania State University Press.

Nussbaum, M. (2001) Upheavals of Thought. The Intelligence of Emotions. Cambridge, UK: Cambridge University press.

Moscovici, S. (2000) Social Representations. Explorations in Social Psychology. Oxford: Blackwell Publisher.

Ojala, M. (2004) 'Emotioner som deliberativa verktyg. Lokala miljökonflikter och känslornas positiva potential', in B. Starrin (ed) Emotionssociologiska uppsatser. Karlstad: Karlstad Universitet (arbetsrapport nr. 1), pp. 73-91

Philo, G. \& Secker, J. (1999) 'Media and Mental Health', in B. Franklin (ed.) Social Policy, the Media and Misrepresentation. London: Routledge, pp135-145.

Rasmussen, J. \& Höijer, B. (2005) Mediebilden av psykisk sjukdom och psykiatrin i samband med våldsbrott. En studie av DN, Aftonbladet och Rapport [Media Representations of Mental Illness and Psychiatric Care in Connection with Violent Crime. A study of DN, Aftonbladet and Rapport]. Stockholm: RSMH.

Reber, A.S. (1985) Dictionary of Psychology. London: Penguin Books.

Robertson, A. (2001) 'Mediated Threats', pp. in Eriksson, J. (ed) Threat Politics. New Perspectives on Security, Risk and Crisis Management. Aldershot, UK: Ashgate, 61-83.

Sandstig, G. (2003) Att undersöka otrygghet. En metodstudie [Investigating Insecurity]. Göteborgs Universitet: Institutionen för journalistik och masskommunikation (report nr. 17).

Smith, C.A. \& Kirby, L.D. 2000. 'Affect and Cognitive Appraisal Processes' pp. 75-91 in Forgas, J. P. (ed) Handbook of Affect and Social Cognition. Mahwah, UK: L. Erlbaum.

Swanson, J.W., et al. (2002) 'The Social-Environmental Context of Violent Behavior in Persons Treated for Severe Mental Illness', American Journal of Public Health 92(9): 1523-1531.

Walsh, E. \& Fahy, T. (2002) 'Violence in Society: Contribution of Mental Illness is Low', British Medical Journal 325: 507-508.

BIRGITTA HÖIJER, Ph.D., Professor, Department of Humanity, Örebro University, SE70182 Örebro, birgitta.hoijer@hum.oru.se

JOEL RASMUSSEN, M.A., Doctoral Candidate, Department of Science, Örebro University, SE-701 82 Örebro, joel.rasmussen@nat.oru.se 